\title{
LIFE CYCLE ASSESSMENT (LCA) IN ENERGY WILLOW CULTIVATION ON PLANTATIONS WITH VARIED SURFACE AREA
}

\author{
Zbigniew Kowalczyk ${ }^{\mathrm{a}^{*}}$, Dariusz Kwaśniewski ${ }^{\mathrm{b}}$ \\ a Department of Production Engineering, Logistics and Applied Informatics, \\ University of Agriculture in Krakow, zbigniew.kowalczyk@urk.edu.pl, \\ ORCID 0000-0001-8001-2092 \\ b Department of Production Engineering, Logistics and Applied Informatics, \\ University of Agriculture in Krakow, dariusz.kwasniewski@urk.edu.pl, \\ ORCID 0000-0002-1873-1456 \\ *Corresponding author: e-mail: zbigniew.kowalczyk@urk.edu.pl
}

\begin{tabular}{|c|c|}
\hline ARTICLE INFO & ABSTRACT \\
\hline $\begin{array}{l}\text { Article history: } \\
\text { Received: November } 2019 \\
\text { Received in the revised form: } \\
\text { December } 2019 \\
\text { Accepted: December } 2019\end{array}$ & \multirow{2}{*}{$\begin{array}{l}\text { The paper carries out a comparative analysis of the production technol- } \\
\text { ogy of energy willow on plantations varied on account of the surface } \\
\text { area in the aspect of the impact on the natural environment. The studies } \\
\text { covered the cultivation of willow in the southern part of Poland. Tech- } \\
\text { nologies from soil preparation for cultivation to first harvesting and } \\
\text { transport to a farm were analysed. A type of the applied technological } \\
\text { treatments, used machines and transport means as well as the time of } \\
\text { their operation, amount of the consumed fuel, pesticides, fertilizers, and } \\
\text { water were taken into consideration. The research results were referred } \\
\text { to the surface area of willow cultivation ( } 1 \text { ha). To determine the envi- } \\
\text { ronmental impact SimaPro program version } 8.1 .0 .60 \text { was used. It was } \\
\text { concluded, inter alia, that cultivation of willow on smaller plantations } \\
\text { constitutes a bigger environmental footprint. }\end{array}$} \\
\hline $\begin{array}{l}\text { Key words: } \\
\text { energy willow, } \\
\text { environmental impact, } \\
\text { environmental footprint, } \\
\text { surface area of plantation, } \\
\text { Life Cycle Assessment ( } L C A\end{array}$ & \\
\hline
\end{tabular}

\section{Introduction}

Biomass has belonged to the most often used renewable energy sources in the recent years which is caused, inter alia, by its considerably low costs of obtaining, high availability and a positive impact on the environment (Dyjakon et al., 2014). Biomass is used for fuel production, which, in turn, can be processed to obtain electrical energy, heat and transport fuels (Igliński et al., 2018; Stolarski et al., 2008). Solid biomass is obtained from the timber industry, urban green, forest waste, agricultural waste, and insignificant amounts from the organic municipal waste. Demand for biomass is rising constantly and since it may be obtained also from the areas which are presently not used economically, it is thus purposeful to use fallowed areas, or wastelands to run plantations of energy plants, inter alia, of energy willow. Stolarski et al., (2008) indicate that obtaining biomass from field plantations of perennial plants may constitute a supplementation of biomass sale on the energy market. 
Bushy willow (Salix viminalis) is quite popular with regard to national energy plantations. Its considerably fast growing and the fact that it is a perennial plant is its value (a plantation of willow may be used for 25-30 years). Timber obtained from cultivation of energy willow has a considerably high heat of combustion $\left(19.3 \mathrm{MJ} \cdot \mathrm{kg}^{-1}\right)$, a low content of ash $(1.3 \%)$ and trace amounts of sulphur: $0.028 \%$ of dry mass (Szczukowski et al., 2014). An attribute of a willow in comparison to forest trees is even a fourteenfold faster increase, on the other hand, from one hectare of a willow plantation during a year one may obtain ca. $30-40 \mathrm{Mg}$ of timber mass which is $15-20 \mathrm{Mg}$ in a dry state, which corresponds to $10-13 \mathrm{Mg}$ of carbon (Sobczyk, 2007). Cultivation of willow for biomass has a great meaning for economy, energy politics and the environment.

Ecological reasons stand behind the increase of biomass use as a renewable energy source since consumption of fossil fuels causes serious effects and thus, inter alia, environmental problems (Krzyżaniak et al., 2016). Due to the environmental aspects of biomass use, its cultivation on plantations, which starts the entire process of energy production should have the smallest negative impact on the environment. One of the methods of assessment of the potential environmental effect of production is the life cycle assessment (LCA). In recent years, the life cycle assessment (LCA) is even more often used for assessment of the potential impact on the environment of production systems (Roy et al., 2009) including for assessment of energy crops and timber production effect on the environment (Caputo et al., 2014; Klein et al., 2015). The LCA is a normalised method of research and comparison that is based on standards ISO 14040-14044. The assessment of the impact on the environment is a tool that serves for identification of the potential impact of the suggested undertaking on the environment, assessment of the alternative approaches and introduction of relevant measures of prevention, management and control (Dyjakon et al., 2018).

Knowledge on the life cycle of biomass production from energy willow is still limited (Nathan et al., 2016) thus further studies are justified. Determination of the environmental burden resulting from the cultivation of energy willow is a significant problem, which, on the other hand should provide a fuller picture of environmental advantages related to replacement of traditional fuels with energy biomass. From the point of view of agricultural engineering, a significant issue is to estimate the impact of machine technologies used in cultivation of energy willow on the environment.

\section{Objective, scope, and method of work}

The aim of the paper is a comparative analysis of the cultivation technology of energy willow on plantations varied on account of the surface in the aspect of their impact on the natural environment.

To determine the environmental relations of all inputs and outputs covered with the scope of the Life Cycle Assessment (LSA) research and estimation of the size of their impact on the environment, SimaPro application version 8.1.060 was applied. In the method a method of assessment of the environmental impact was used - ReCiPe Endpoint. Endpoint indicators which pictures the impact of the environment on three aggregation levels, namely: 1) effect on human health, 2) biodiversity, ecosystem and 3) resource scarcity. Environmental impact (EI) was calculated in the so-called units of general nuisance $(\mathrm{Pt})$ used quite often in the LCA method and referred to one hectare of cultivation. Figure 1 presents the limits of the system. 
The analysis covered only activities related to setting up a plantation, its treatment in one year and harvesting and transport of the cut biomass. The scope of the analysis did not concern post-harvest activities of the collected biomass. During the analysis also the used seedlings of willow were not included because there was no such a position in catalogues of SimaPro program.

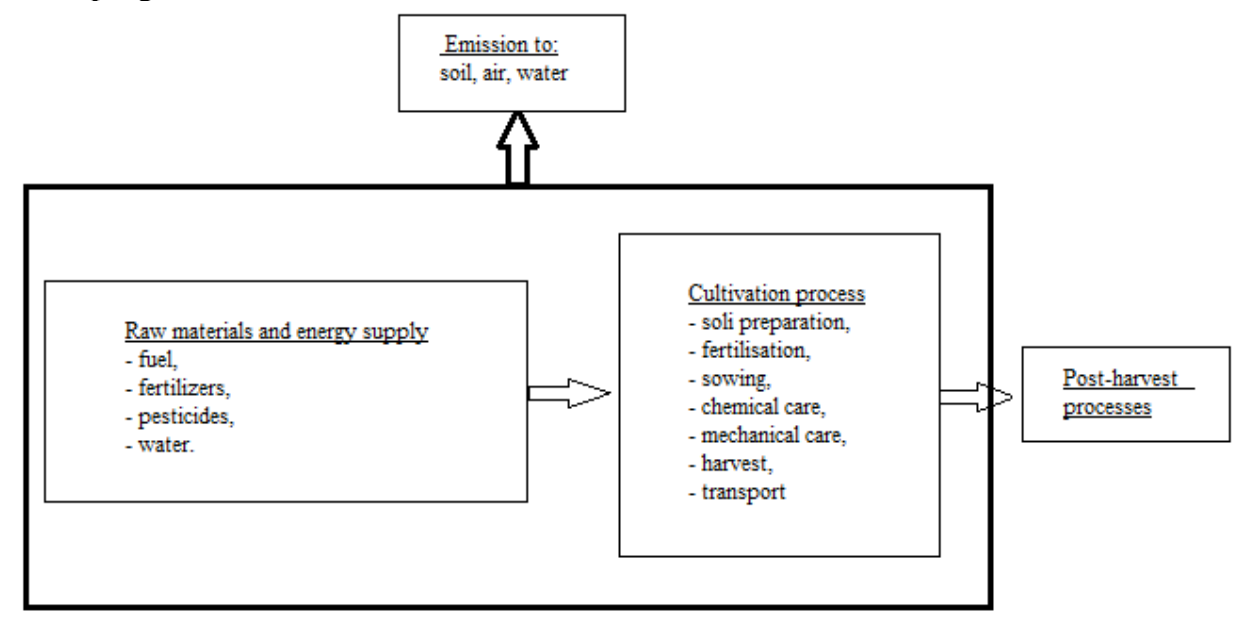

Figure 1. Limits of the system

The research covered 15 plantations of energy willow located in the south of Poland. Selection of plantations of willow was purposeful, i.e. five plantations with a considerably small area (at the average 0.48 ha) were selected - group I, five bigger with an average area of 2.08 ha included to group II and five the biggest (average area - 8.06 ha) - group III.

\section{Research results}

Table 1 presents general information concerning a plantation of energy willow selected for the research. The yield of the fresh biomass after the first year of cultivation was from $6.8 \mathrm{t} \cdot \mathrm{ha}^{-1}$ in group I to $9.4 \mathrm{t} \cdot \mathrm{ha}^{-1}$ in group II. The plantations were located considerably close to a farm, at the average from $0.8 \mathrm{~km}$ to $1.4 \mathrm{~km}$ which had an impact on the amount of transport works.

Table 2 sets production means used in cultivation technologies of willow in certain groups. The amount of materials and energy included in each process were calculated based on the earlier research carried out in farms cultivating energy willow. The studies consisted in registration of technological operations related to cultivation. Sizes of the so-called clean element of fertilisers expressed with the value: $\mathrm{N}, \mathrm{P}_{2} \mathrm{O}_{5}$ and $\mathrm{K}_{2} \mathrm{O}$ prove that mineral fertilizers were considerably rarely used and only on the selected plantations from group II and III. On the other hand, the highest consumption of pesticides (at the average $3.42 \mathrm{~kg} \cdot \mathrm{ha}^{-1}$ was reported in the group of the smallest plantations. Herbicide Roundup was the most often used pesticide. It was applied before setting up a plantation to combat weeds. Plantations of willow 
were not artificially hydrated, and the water consumption presented in table 2 was related to the use of chemical crop protection treatments. Soil preparation was quite similar in all groups. Soil preparation consisted in mechanical cultivation, namely ploughing, with a cultivator and harrowing. Sometimes also tillage or soil milling was applied. Willows were seeded manually. Weeding was made manually or with tractor drill hoes. Harvesting was in general manual with the use of pruning shears and only in the group of bigger plantations board mowers for cutting willow were used. Agricultural tractors and trailers were used for transport. A low degree of mechanised works results mainly from a small surface area of the owned plantations which is confirmed by Kwaśniewski's research (2006) according to which on the area of the southern Poland, usually plantations of willow with a small acreage occur, additionally far away from each other which is an economic barrier for using mechanised technologies.

Table 1.

General information concerning plantations covered by the research

\begin{tabular}{lcccc}
\hline $\begin{array}{l}\text { Area } \\
\text { group }\end{array}$ & $\begin{array}{c}\text { Surface area } \\
\text { Min-max (average) } \\
\text { (ha) }\end{array}$ & $\begin{array}{c}\text { Number } \\
\text { of planta- } \\
\text { tions }\end{array}$ & $\begin{array}{c}\text { Yield of fresh } \\
\text { biomass } \\
\left(\mathrm{t} \cdot \mathrm{ha}^{-1}\right)\end{array}$ & $\begin{array}{c}\text { Distance } \\
\text { Min-max (average) } \\
(\mathrm{km})\end{array}$ \\
\hline I & $0,31-1,00(0,48)$ & 5 & $5,9-7,2(6,8)$ & $0,6-1,6(1,2)$ \\
II & $1,20-4,00(2,08)$ & 5 & $8,1-10,2(9,4)$ & $0,9-1,7(1,4)$ \\
III & $5,19-12,00(8,06)$ & 5 & $7,2-8,7(7,8)$ & $0,4-1,1(0,8)$ \\
\hline
\end{tabular}

Table 2 .

Selected means of production used in cultivation of energy willow

\begin{tabular}{lcccc}
\hline \multirow{2}{*}{ Description } & Unit & \multicolumn{3}{c}{ Area group } \\
\cline { 3 - 5 } & & I & II & III \\
\hline Mineral fertilizers & & & & \\
$-\mathrm{N}$ & $\left(\mathrm{kg} \cdot \mathrm{ha}^{-1}\right)$ & 0 & 2.77 & 0.79 \\
$-\mathrm{P}_{2} \mathrm{O}_{5}$ & $\left(\mathrm{~kg} \cdot \mathrm{ha}^{-1}\right)$ & 0 & 8.32 & 2.38 \\
$-\mathrm{K}_{2} \mathrm{O}$ & $\left(\mathrm{kg} \cdot \mathrm{ha}^{-1}\right)$ & 0 & 8.32 & 2.38 \\
Pesticides & $\left(\mathrm{kg} \cdot \mathrm{ha}^{-1}\right)$ & 3.42 & 3.23 & 1.36 \\
Diesel & $\left(1 \cdot \mathrm{ha}^{-1}\right)$ & 138.5 & 145.6 & 134.9 \\
Water & $\left(1 \cdot \mathrm{ha}^{-1}\right)$ & 201.3 & 198.4 & 115.7 \\
\hline
\end{tabular}

Figures 2-4 an environmental footprint related to cultivation of willow on plantations in particular groups was presented. Generally, when analysing the size of the environmental footprint one may notice a clear predominance of transport over all technological operations. Such state of affairs results mainly from a considerable consumption of fuel (diesel oil). Although, the mass transported after harvesting was not big, it had a great volume, therefore the use of transport means. Moreover, organization of work (manual harvesting) caused that transport means also worked on the area of a plantation during loading of the cut biomass. When comparing Pt value for transport works in all groups, one may notice that in groups I and II, these values are at a similar level and are respectively: $118 \mathrm{Pt}$ and $110 \mathrm{Pt}$ while in the biggest plantations, the environmental footprint is at the level by half lower $(55 \mathrm{Pt})$. Such 
state of affairs results partially from a smaller transport distance (table 1) and from the use, in case of the biggest plants, transport means with a considerably bigger volume of the load bed and better organization of works at harvesting resulting, inter alia, from the use of mechanical harvesting. The second position as to the size and with regard to the environmental impact of particular technological operations constitutes preparation of soil, and thus cultivation operations. Naturally, operation of cultivation machines, due to a considerable loading of working elements is related to a higher consumption of fuel by engines of agricultural tractors. The environmental footprint related to preparation of soil is also the lowest in the group of the biggest plantations with regard to the area and is $31 \mathrm{Pt}$, while in the group I - $41 \mathrm{Pt}$ and group II - $38 \mathrm{Pt}$. Undoubtedly, the environmental footprint is also influenced by the level of modernity of machines and the size of the unit consumption of fuel during works. In the course of the studies is was reported that on bigger plants, works with the use of a more modern equipment, including farm tractors, were performed. From among the remaining technological operations, mineral fertilizations also distinguished (in group II and III), where the value of the environmental footprint, measured in Pt units is respectively: 9.6 and 13.5 which results from mineral fertilisers which burden the environment.

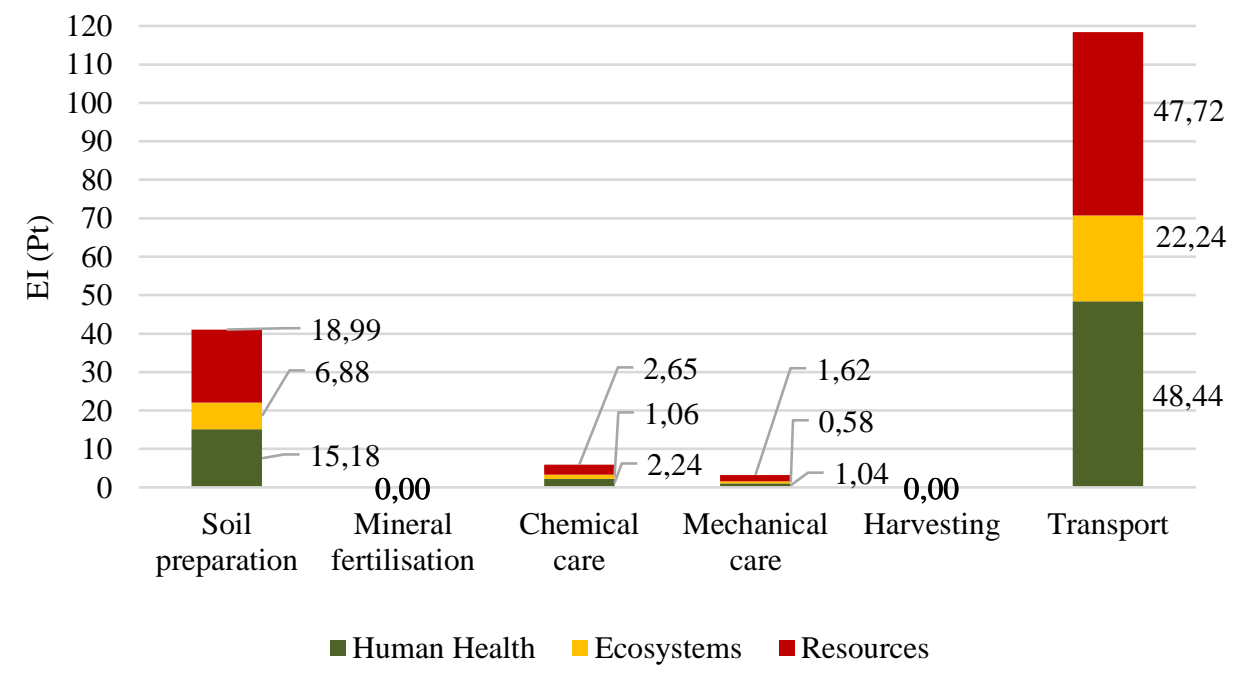

Figure 2. Environmental impact of willow cultivation technology in group I 
Zbigniew Kowalczyk, Dariusz Kwaśniewski

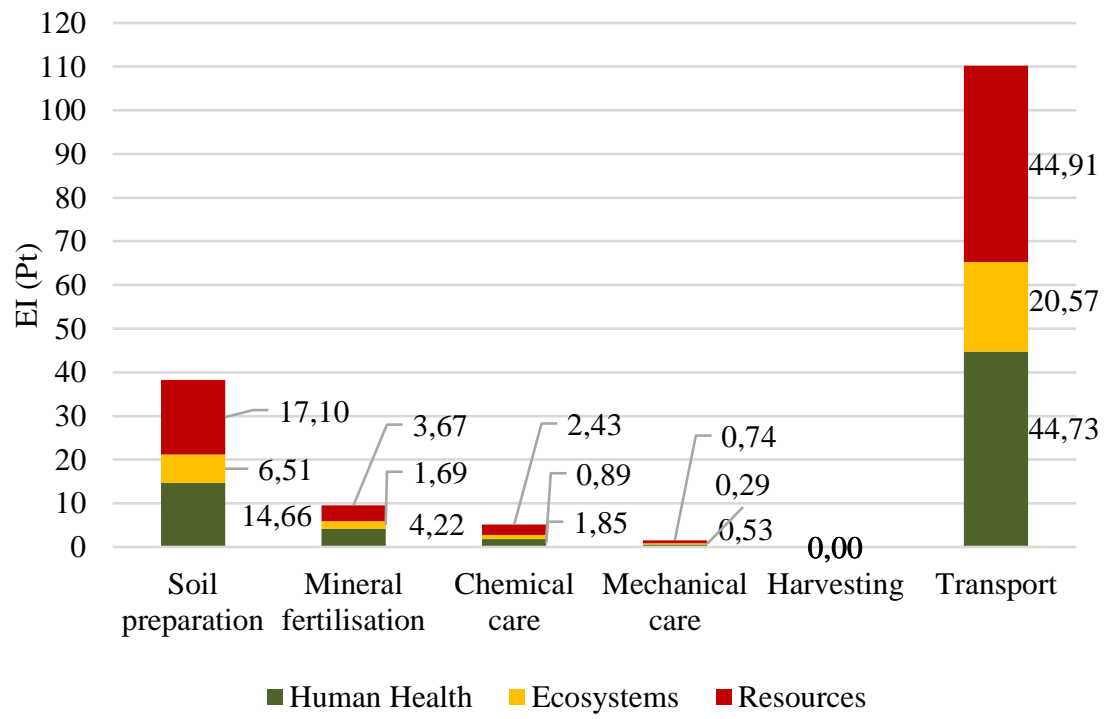

Figure 3. Environmental impact of willow cultivation technology in group II

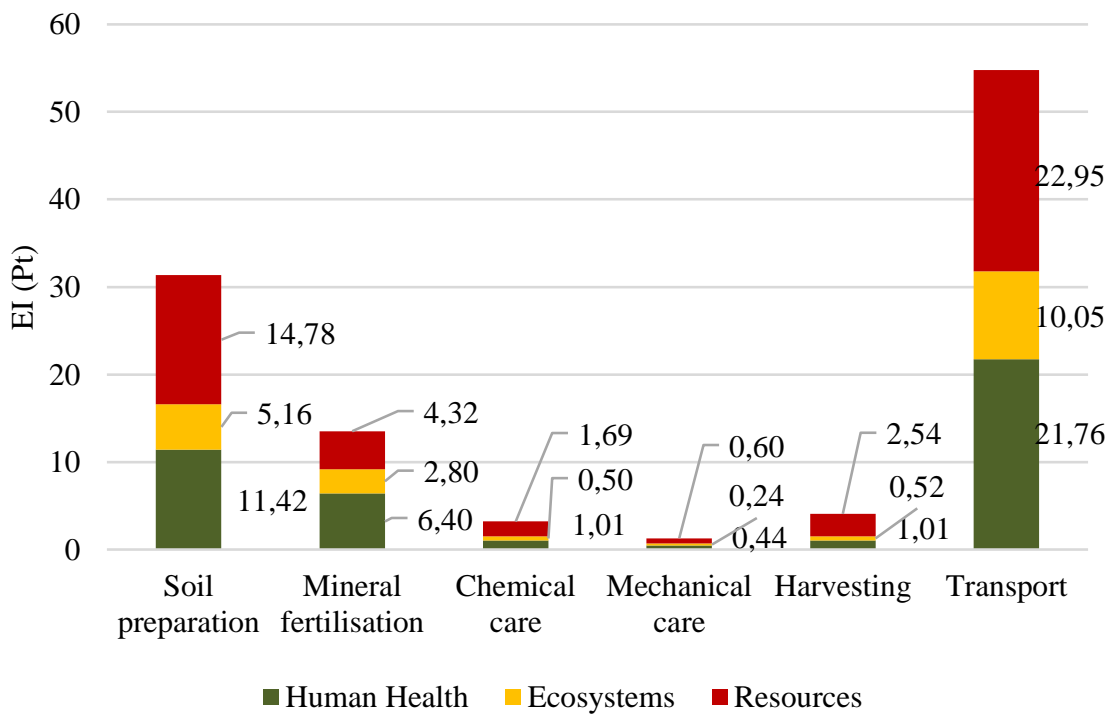

Figure 4. Environmental impact of willow cultivation technology in group III 
Figure 5 presents a structure of the total environmental footprint in cultivation of willow in three area groups. One may notice in the course of analysis, that the level of the total environmental footprint of the cultivation in group I and II is at a similar level and is respectively: 169 and $165 \mathrm{Pt}$. On the other hand, in the group of the biggest plantations, the value of the environmental footprint is at the level of $108 \mathrm{Pt}$. Due to varied methodologies of the environmental footprint calculations and mainly various limits of the system are assumed in the course of the research, it is difficult to clearly compare the obtained results to the ones available in the subject literature concerning the impact of energy willow cultivation on the environment. To compare, the environmental footprint in potato cultivation estimated with the use of the same method is approximately $280 \mathrm{Pt}$ (Kowalczyk, 2019).

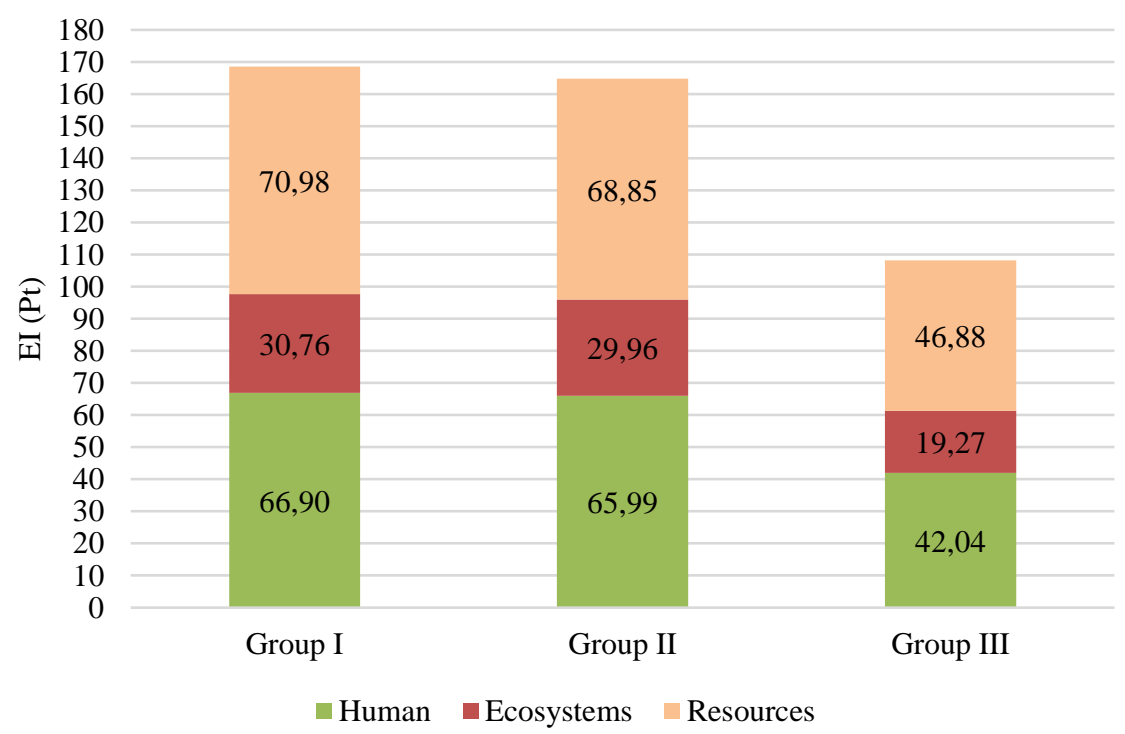

Figure 5. Level and structure of the environmental impact of the willow cultivation technology in three area groups

The environmental footprint structure presents the impact of the willow cultivation technology on the environment in three aspects: human health, ecosystem, and resources. By consideration of the environmental impact of willow cultivation in particular categories (figure 5), one may notice that in case of all groups, this structure is analogous. The most, because in $41-44 \%$, the cultivation affects the natural resources of raw materials. This category is related to, inter alia, excavation of minerals and fossil raw materials. Secondly (38-40\%) cultivation of energy willow negatively affects the environment in category "human health". As a part of this category, such factors as a number and duration of diseases, deaths caused by the environmental impact etc. occur. Contrary, to the lowest extent (17-19\%) cultivation 
technologies of the energy willow affect the quality of ecosystems. The "ecosystems" category concerns the impact on variability of species, especially plants and on the following effects: ecotoxicity, acidity, eutrophication, and soil exploitation.

\section{Statements and conclusions}

Based on the research which was carried out on AD3.152 engine it was found out that:

1. The environmental impact of energy willow cultivation depends on the plantation size. The use of a newer and more efficient agricultural equipment and better organization of works on bigger plants (group III) cause reduction of the unfavourable environmental footprint by $38 \%$ compared to the group of the smallest plantations.

2. Regardless the surface area of plantations, from among all technological activities, the highest impact on the environment have transport means whose participation in the total size of the environmental footprint in certain groups is from $51 \%$ to $70 \%$. Such state of affairs results, among others, from improper organization of harvesting and application of transport means, especially on small plantations and low volumetric mass of the collected biomass from willow.

3. Two elements have a prevailing position in the structure of the environmental footprint, regardless the plantation size, namely: Resources (41-44\%) and Human health (38-40\%). The willow cultivation considerably less affects the Ecosystems (17-19\%).

4. Cultivation of the energy willow, included to renewable sources must bring, inter alia, considerable environmental advantages and the biofuels produced from biomass should constitute an alternative to fossil fuels. Due to the above, growers who deal with its cultivation should thoughtfully select a cultivation technology and the machinery equipment since these factors considerably precondition the degree of the environmental footprint.

\section{References}

Caputo, J., Balogh, S., Volk, T., Johnson, L., Puettmann, M., Lippke, B., Oneil, E. (2014). Incorporating uncertainty into a life cycle assessment (LCA) model of short-rotation willow biomass (Salix spp.) crops. BioEnergy Research 7, 48-59.

Dyjakon, A., den Boer, J., García-Galindob, D., Adamczyk, F., Lopezb, E., Sebastian, F., Suardid, A., Gebresenbete, G., Jirjise, R., Bosonae, T., Germerf, S., Bischoff, W. (2018). Orchards pruning to energy - the results of the environmental impact assessment of the new logistic chain developed within the europruning project - part 2, Agricultural Engineering, 22, 37-48.

Dyjakon, A., den Boer, J., Bukowski, P. (2014). Europruning - a new direction for energy production from biomass. Agricultural Engineering, 3, 29-39.

Igliński, B., Cichosz, M., Skrzatek, M., Buczkowski, R. (2018). Potencjał energetyczny biomasy na gruntach ugorowanych i nieużytkach w Polsce. Inżynieria i Ochrona Środowiska, 21, 79-87.

Klein, D., Wolf, Ch., Schulz, Ch., Weber-Blaschke, G. (2015). 20 years of life cycle assessment (LCA) in the forestry sector: state of the art and a methodical proposal for the LCA of forest production. International Journal of Life Cycle Assessment, 20, 556-575.

Kowalczyk, Z. (2019). Environmental impact of potato cultivation on plantations covering areas of various sizes. E3S Web of Conferences, 132: 02002.

Krzyżaniak, M., Stolarski, M., Szczukowski, S., Tworkowski1, J. (2016). Life Cycle Assessment of New Willow Cultivars Grown as Feedstock for Integrated Biorefineries. BioEnergy Research, 9, 224-238. 
Life cycle assessment (LCA)...

Kwaśniewski, D., Mudryk., K., Wróbel, M. (2006). Zbiór wierzby energetycznej z użyciem piły łańcuchowej. Inżynieria Rolnicza 13, 271-277.

Nathan, J., Sleight, N., Volk, T. (2016). Recently Bred Willow (Salix spp.) Biomass Crops Show Stable Yield Trends Over Three Rotations at Two Sites. BioEnergy Research 9, 782-797.

Roy, P., Nei, D., Orikasa, T., Xu, Q. , Okadome, H., Nakamura, N., Shiina, T. (2009). A review of life cycle assessment (LCA) on some food products. Journal of Food Engineering, 90, 1-10.

Sobczyk, W. (2007). Plonowanie wierzby wiciowej - w świetle badań. Polityka Energetyczna, 10(2), 547-556.

Stolarski, M., Szczukowski, S., Tworkowski, J. (2008). Biopaliwa z biomasy wieloletnich roślin energetycznych. Energetyka, 1, 77-80.

Szczukowski, S., Stolarski, M.J., Tworkowski, J., Rutkowski, P., Goliński, P., Mleczek, M., Szentner, K. (2014). Plon i jakość biomasy wybranych gatunków wierzby w czteroletniej rotacji zbioru. Fragmenta Agronomica, 31(2), 107-114.

\section{LIFE CYCLE ASSESSMENT (LCA) W UPRAWIE WIERZBY ENERGETYCZNEJ NA ZRÓŻNICOWANYCH OBSZAROWO PLANTACJACH}

Streszczenie. W pracy dokonano analizy porównawczej technologii produkcji wierzby energetycznej, na zróżnicowanych pod względem powierzchni plantacjach, w aspekcie wpływu na środowisko naturalne. Badaniami objęto uprawę wierzby w południowej części Polski. Analiza dotyczyła technologii od przygotowania gleby pod uprawę, aż po pierwszy zbiór oraz transport do gospodarstwa. Wzięto pod uwagę: rodzaj stosowanych zabiegów technologicznych, wykorzystywany sprzęt maszynowy i środki transportowe oraz czas ich pracy, ilość zużytego paliwa, pestycydów, nawozów oraz wody. Wyniki badań odniesiono do powierzchni uprawy wierzby (1 ha). W celu określenia wpływu środowiskowego, zastosowano program SimaPro, wersja 8.1.0.60. Stwierdzono m. in., że uprawa wierzby na mniejszych plantacjach stanowi większe jednostkowe obciążenie dla środowiska.

Słowa kluczowe: wierzba energetyczna, wpływ środowiskowy, obciążenie środowiskowe, powierzchnia plantacji, Life Cycle Assessment (LCA) 